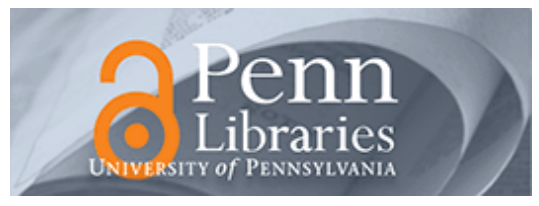

University of Pennsylvania

ScholarlyCommons

Management Papers

Wharton Faculty Research

$11-2003$

\title{
The Strategic Organization of Political Risks and Opportunities
}

Witold J. Henisz

University of Pennsylvania

Bennet A. Zelner

Follow this and additional works at: https://repository.upenn.edu/mgmt_papers

Part of the Business Administration, Management, and Operations Commons, and the Organizational Behavior and Theory Commons

Recommended Citation

Henisz, W. J., \& Zelner, B. A. (2003). The Strategic Organization of Political Risks and Opportunities.

Strategic Organization, 1 (4), 451-460. http://dx.doi.org/10.1177/14761270030014005

This paper is posted at ScholarlyCommons. https://repository.upenn.edu/mgmt_papers/78

For more information, please contact repository@pobox.upenn.edu. 


\section{The Strategic Organization of Political Risks and Opportunities}

Disciplines

Business Administration, Management, and Operations | Organizational Behavior and Theory 


\title{
Political Risk Management: A Strategic Perspective
}

by

\author{
Witold J. Henisz \\ and \\ Bennet A. Zelner
}

WP 2002-06

A Working Paper of the Reginald H. Jones Center

The Wharton School University of Pennsylvania 


\title{
Political Risk Management: A Strategic Perspective
}

\author{
Witold J. Henisz and Bennet A. Zelner* \\ The Wharton School \\ University of Pennsylvania \\ Philadelphia, PA 19104-6370 \\ henisz@wharton.upenn.edu \\ 215-898-0788 \\ and \\ McDonough School of Business \\ Georgetown University \\ Washington D.C. 20057-1147 \\ zelnerb@georgetown.edu \\ 202-687-6087
}

* We thank the GE Fund and The Reginald H. Jones Center for Management Policy, Strategy, and Organization for their generous financial support. 
Although insurers often treat political risk as a country-specific phenomenon, substantial variation in the probability and magnitude of loss exists at the firm level. Individual firms confront different sources of policy uncertainty and political influence depending on factors such as their size, nationality, familiarity with the local environment, partner status, technological leadership and network of global stakeholders. Sophisticated managers address political risk by employing tailored risk mitigation strategies that reflect the specific factors affecting a firm's risk profile. Insurers may therefore determine the proper scope and price more accurately and efficiently by assessing the fitness of a given political risk mitigation strategy.

In this paper we provide a simple framework that can be used to make such an assessment. The framework revolves around a firm's bilateral "bargain"-its implicit or explicit agreement about what portion of its returns it will appropriate-with a host country government. Over time, the government is likely to face electoral, financial or economic incentives to increase the fraction of the firm's returns that get redistributed to competitors, suppliers, buyers or the broader polity. We develop our framework by first identifying the factors that imbue a foreign firm with "bargaining power" that it may exploit to protect its initial bargain. We next consider how a firm's industry position affect the optimal form of the arguments that its managers make in attempting to influence the policymaking process. Finally, we discuss the dynamic integrity of a firm's political risk mitigation strategy, i.e., the extent to which the strategy balances shortterm profitability with resistance to the future political backlash that could result from the appearance of privilege or inequity. The choices that management makes in all three of these areas affect the probability and likely magnitude of a firm's loss from adverse government behavior. 
We draw from extensive field interviews in the electricity generation and cellular service industries of thirteen emerging markets in East Asia, South America and Central Europe to support our arguments. ${ }^{1}$ Managers at all of the firms that we visited stressed the importance of their government and public relations functions in reduc ing the probability and severity of attempts by public officials - acting in the interest of consumers, competitors, suppliers, potential entrants or other interested parties - to squeeze profits out of the firm. Such attempts typically took the form of policy decisions that altered the terms of existing contracts, the structure of the market or the firm's latitude to set prices or make new service offerings. Key determinants of success to which many interviewees pointed included active monitoring of the political and regulatory arena as well as participation in policy debates.

Non-infrastructure industries may face less policy uncertainty or fewer policy initiatives that affect them directly. Nonetheless, managers who recognize that political risk is ubiquitous and learn to manage it effectively over time have an opportunity to outperform their counterparts in a wide array of industrial and country environments. In the words of one manager, "governance is as important as value." Indeed, surveys of multinational managers across industries repeatedly underscore the impact of the policy environment on international investment decisions and outcomes. ${ }^{2}$ For example, a survey of 3,951 firms in 74 countries found that corruption and judicial unpredictability were the second and third most serious obstacles to doing business, following only taxation. ${ }^{3}$ A similar survey of the largest global multinational

\footnotetext{
${ }^{1}$ Argentina, Brazil, Chile, The Czech Republic, Hungary, Indonesia, Malaysia, The Philippines, Poland, Singapore, South Korea, Taiwan and Thailand.

${ }^{2}$ See Korin et. al. (1980); Root (1968) and Pfeffermann and Kisunko (1999).

${ }^{3}$ See Pfeffermann and Kisunko (1999).
} 
corporations found that "unconventional" risks such as corruption, crony capitalism and political risk cost firms US \$24 billion in lost revenue in 1998 alone, leading 84 percent of subsidiaries in emerging markets to fall short of their financial target and ultimately to an eight to 10 percent diminution in total corporate returns. ${ }^{4}$ Another recent report concerning the economic significance of governance (broadly defined) found that investors contemplating entry into countries with "opaque" governance (e.g., China, Russia, Indonesia, Turkey, South Korea, Romania and the Czech Republic) faced the equivalent of a 33 to 46 percent increase in corporate income taxes, relative to the cost of entering a country with stronger governance (e.g., the United States or Chile). ${ }^{5}$ Similarly, an analysis of portfolio debt flows found that bondholders in countries with opaque governance demanded premiums of 9.00 to 13.16 percent.

While these aggregate statistics are compelling, they mask the underlying firm- and project-level heterogeneity acknowledged by industry participants. Consider, for example, the following comments (drawn from Moran [, 2001 \#4273; 1998 \#4272]):

- “...effective political risk analysis is not just a question of evaluating country risk. Instead, risk assessments must identify the implications of social, political and economic conditions for each particular project... The key to analyzing the political risks facing a project is to identify the winners and losers and assess their relative abilities to help or hinder a project, wither directly or by influencing a host government.” [Markwick, 1998 \#4414: 55]

- "I prefer to focus on what my assured can bring to a risk. My reasoning is that if you back the right assured, you can usually keep problems from occurring in the first

\footnotetext{
${ }^{4}$ See Merchant International Group (1999).

${ }^{5}$ See Wei and Hall (2001).
} 
place — and if they do happen, you have an excellent chance of mitigating your loss. [James, 2001 \#4413: 172]

- "There is no such thing as abstract political risk in my opinion: political risk very much depends on who you are and what you are doing in a country. [Berry, 2001 \#4416: 181]

- 'Zurich's view is that the insured is the most crucial part of risk assessment, because it is the experience and capabilities of the insured that will ultimately have the largest impact on risk in the long term.” [Riordan, 2001 \#4417: 189]

These practitioners highlight an insured's size, nationality, familiarity with the local environment, partner status, technological leadership and network of global stakeholders as relevant criteria for political risk analysis. Our framework provides insight into why these criteria matter and augments this initial list with new considerations.

\section{Creating Bargaining Power}

Ultimately, any attempt to influence a policy decision requires managers to participate in the political debate. Their success in doing so depends as much on their level of bargaining power relative to the host country government as it does on the actual arguments that they make (which we consider below). Investor bargaining power is often argued to be at its maximum in the negotiation phase when the investor has the capital and technology that the government needs to create jobs, output, technology transfer and promote additional foreign direct investment, and then to decline after the investor has sunk its capital. Some of the factors that can affect the rate of decline lie outside of management's immediate control. For example, government officials are typically thought to be more sensitive to the demands of a large firm providing substantial local employment and income than they are to those of a smaller firm offering fewer benefits to their 
constituents. Global size may also convey reputational benefits to investors or provide them with room for added flexibility in response to adverse policies that similarly increase policymakers' sensitivity to investor needs.

Yet managers may still improve their firm's bargaining position by making choices that are under their control so as to increase the host country's dependence on their local subsidiary. A common means of doing so is to deploy non-replicable technology (embodied in the production process itself or in an intermediate product) owned by the parent firm. One oil company with drilling operations in Russia, for example, deployed advanced technology that only its specially trained engineers could operate through a freeze and thaw cycle of permafrost. ${ }^{6}$ The oil company's leverage was high in this case because the Russians would have been unable to maintain production if the company and its employees exited the country. The incentives for government officials to squeeze the company through adverse policy changes were therefore much lower than they would have been had the company used generic technology that the Russians would be able to operate even in its absence.

Even where the range of technological choices that managers can make to increase their bargaining leverage is limited, they may find opportunities to create leverage through external relationships. One such channel is the foreign company's home country government. Interviewees in Poland (speaking of the 1989-1992 period) and Taiwan described to us their governments' susceptibility—especially given their role in US foreign policy—to lobbying efforts undertaken by the US government on behalf of American firms. Observers in Central Europe highlighted the recent lobbying prowess of the German and French governments on

\footnotetext{
${ }^{6}$ See Spar (1995).
} 
behalf of France Telecom and Deutsche Telekom in light of host country governments' desire for EU accession at the earliest possible date.

Foreign investors may also exploit direct ties with home country political officials to create external leverage relative to a host country government. One former regulator told us that when he "assessed a $\$ 4$ million penalty on the companies from [country $\mathrm{x}$ ] and [country y], they claimed force majeur and put their embassies to work to lobby our government." Another prominent example involves Texas-based Enron Corporation's investments in Argentina. A former regulatory official there (now a Congressmen) claims to have received a phone call in early 1989 from George W. Bush, the son of then President-elect George H.W. Bush, which delivered "a subtle, vague message that [helping Enron] could help us with our relationship to the United States" (Corn, 2002). Finally, even in the absence of a specific source of external leverage, the more nebulous threat of an angry public combined with good old-fashioned brinksmanship can be quite effective. One interviewee recounted a perilous 90 minutes in his project's history: "[Our pricing dispute] came down to a final phone call with the Ministry where we threatened not to put our plant into operation, resulting in lawsuits from the contractor and offtaker which would result in a counter-suit by us against the government. We promised them that this would be a very public and very dirty affair and asked them, what are you going to do? Less than two hours later we agreed on a price."

Managers often create external leverage through non-governmental organizations as well. For example, one manager that we interviewed described his threat to alert the financial rating agencies of worsening relations between his company and the government as an important source of external leverage. Others emphasized the leverage that they were able to attain through their ties with international banking syndicates, government-sponsored political risk underwriters 
(e.g., OPIC, the Export-Import Bank, COFACE, ECGD, MITI etc.) and multilateral lending agencies (e.g., the Asian Development Bank and the International Finance Corporation).

Investors in wireless telecommunications, for example, have relied on the WTO to reduce formal local ownership requirements and liberalize the sector. For publicly-traded firms, shareholdersespecially foreign and institutional ones - can provide external leverage as well, as aninvestor in Chile explained. So too can ties with industry associations, which can participate in lobbying and public education, as the Association of Foreign Generators did on behalf of investors in the Philippine electricity sector.

Efforts to build bargaining power are especially important when a new market includes politically powerful incumbents that possess strong ties to government institutions or officials. Because a foreign entrant can do little in the short run to sever such ties, managers need to analyze the non-market environment as carefully as the market environment in order to develop realistic performance expectations. Alternately, managers may want to undertake a detailed analysis of the non-market structure in order to evaluate potential local partners, whose political ties could then benefit the foreign entrant.

The Czech electricity market provides an example. Many private entrants there allege that the government accords special treatment to the partially privatized former monopolist CEZ. They claim that the regulatory formula used to determine the fees that they pay to CEZ for access the national transmission system are "cooked to help CEZ," which has massive debt through its subsidiary. Even the Ministry of Finance has attacked the lack of transparency in the design of the new formula (Johnstone, 2001). United Energy has filed a lawsuit, claiming that the fee was calculated by a consultant hired under closed tender rather an open competition. Nonetheless, the formula remains in place for the time being, demonstrating just how powerful 
an incumbent's ties to the government can be. As is often the case, CEZ's ties date back to the pre-privatization period-i.e., prior to entry by any of the private firms - suggesting that an analysis of the non- market environment might have identified the possibility of privileged regulatory treatment. Moreover, the unfortunate experience of the investors who did enter has led many international operators to stay away from the Czech market altogether-unless they can enter by buying into a privatized CEZ.

In the wireless telecommunications industry, a similar situation exists with fixed line carriers, mainly those that retain some degree of state of ownership and enjoy preferential political treatment as a result. One interviewee explained that "all the rules are right. The problem is the execution. The outcome, the execution, they always favor [the fixed line carrier]." Another lamented that it is "hard to fight a player and a referee that are on the same team," while a third averred that the fixed line incumbent "takes advantage of its relationship with the (Government). They postpone deadlines and cooperate reluctantly...they lobby to reduce the budget of the [regulator] which reduces its ability to hire professional experts to inspect and monitor them." For reason such as this, foreign entrants in many cases have allied themselves with fixed-line incumbents through equity investments, partnerships and the like. Examples include the recent partnership between France Telecom and TPSA in Poland, the acquisition and partnership strategies of such firms as MCI, Telefonica, Telecom Italia and Bell Canada in Brazil and France Telecom and Telecom Italia's joint ownership of Telecom Argentina.

Sometimes existing political ties require a deeper political analysis than evaluation of the incumbent(s) alone. In the Polish cellular sector, for example, a political coalition has dictated the structure of market, in this case to the disadvantage of the state-owned fixed line operator and its foreign partner France Telecom. In 1996, the Peasant Party (PSL) controlled the Minister of 
Telecommunications and consequently also held the reins of the state-owned firm TPSA. TPSA chose not participate in a GSM license tender in that year (much to the consternation of its American joint venture partner Ameritech), paving the way for the government to award new licenses to two new private consortia. TPSA's decision appears puzzling without recognition of the strong ties among the PSL, its coalition partner the SLD, and the two new consortia receiving the license. According to one interviewee, "these consortia were created for political reasons by people without experience in the market." Another concurred, "the Polish partners had no operational experience in telecommunications but did help with lobbying." The Financial Times summarized the ket relationships: "one license would be awarded to Elektrim [the former stateowned trading enterprise that had a monopoly on foreign trade in telecommunications and electricity products in the Communist era], which has political links with the Left Democratic Alliance (SLD), the senior governing coalition partner, while the other license would be awarded to Ciech [the former state-owned trading enterprise that had a monopoly on foreign trade in oil and chemical products in the Communist era] with strong links to the Polish Peasant Party (PSL).” (Financial Times Business Reports Business File, 1995)

Similar examples abound. In Thailand, the Prime Minister has proposed legislation restricting foreign investment but provided an advantage to the telecommunications firm AIS by "grandfathering" in its shareholders. Our interviewees in Taiwan ascribed the success or failure of private wireless telecommunications entrants relative to incumbent Chunghwa Telecom to their ties to the DPP and KMT parties.

Entrants seeking to create leverage vis-à-vis foreign governments thus have several options. In addition to making clever choices about technology, they may utilize various external channels to increase their bargaining power, and they may also choose to ally 
themselves with incumbents that already possess such power. Assessing the non- market environment of a potential host country is a necessity in any case in order to make realistic projections about the future.

\section{Framing the Arguments}

We now shift focus from the structure of "bargaining" with a host country government to its content. Simple demands for more profits are seldom successful; instead, such must tap into some policy goal such as "fair competition" or a "level playing field" that resonates with a broad class of constituents and thereby increases popular support of an initiative. Moreover, the precise form of such arguments depends on the position of the firm in the industry as well as the extent to which it is in a offensive position or a defensive one.

Foreign entrants taking the offensive on their own often argue for the long-term benefits of free competition - with the stipulation that a system of asymmetric regulation favoring the entrants over the incumbent(s) is initially necessary to create a level playing field. Consider some of the specific arguments made by entrants in the wireless telecommunications sector, which where virtually identical in the countries that we visited.

- "Of course we have pushed for asymmetry. Our concept is for a level playing field. If one firm starts with a huge lead, you are not going to get competition by treating everyone equally. Unless you tilt the market so that the dominant firm cannot abuse its market power, you will never have true competition."

- "It's like giving a 70m head start in a 100m race and asking who will win."

- "However hard we try to improve the situation, the structure of the market itself makes it hard to catch up with the frontrunners... What we want is not outright 
favors but a market environment where frontrunners and latecomers are allowed to stage fair competition."

When on the defensive rather than the offensive, foreign entrants tend to focus more on the inefficiency of the incumbent rather than its power in the market. In Hungary, for example, fixed- line operators caught off guard by the substitution of mobile telephony for traditional service sought redress from the government through the imposition of a universal service fee and a re-regulation of fixed-to-mobile tariffs to compensate them for the higher costs of serving rural and relatively poor regions. The ensuing public relations battle saw entrants highlighting the mistakes made by incumbents in an attempt to avoid these cost burdens: "the only one way that they can survive is from subsidies. They go to the government to demand something from the mobile sector. The government is afraid that if they don't give them what they ask for, they will go bankrupt and 30,000 to 40,000 customers will have no local service. It would have been much better to let them go bankrupt then we would not be in this blackmailing situation today." Another interviewee concurred, "they saw no way to survive the takeover of mobile telephony other than to lobby the government to change the interconnection regime...Fixed line services are still perceived as the way to reach the masses. Mobile is somehow ugly: compact, trendy, high profile, a symbol of status and expensive." A cellular operator in another country summarized the concerns of new entrants regarding such appeals: "The bottom line is that [they] want some of our money. Everything that they say translates as 'we want some of your money.'"

The nature of the arguments changes when an entrant allies itself with an incumbent. The offensive posture in this case takes the form of an argument for unfettered competition:

- “After 2006, we need to have equal terms. We can't try to make up for the past. At the time, the bidding was open. Those who won the bids have a right to win." 
- "The danger of asymmetric regulation is that it will be applied in a manner that discriminates against the large operators without regard to whether they arrived at their position through a special deal or through efficient business practices."

- "I question whether these new entrants are even that efficient. They have such a heavy reliance on government."

- “The late entrant applications were not conditional on asymmetry. They didn't even mention it. Now they give all these reasons." "The problem is that [they] priced their service below cost and so ran into serious financial problems... Now, they are asking for asymmetric regulation."

- "Most of the disputes here are coming from the third operator. They are asking for better treatment... arguing that they are poor." Another interviewee explained the reason for the operators weak position as follows, "Their license stipulated certain fixed prices. They claimed that at those prices they couldn't make a profit and asked for better terms but they knew the fixed prices when they bid."

When on the defensive, the incumbent and its foreign partner again focus on the incumbent's inefficiency, but in this case by citing the burden of additional costs incurred to serve a public need. They note that incumbent firms with current or past state ownership typically face great difficulties in reacting quickly to changing market conditions due to government bureaucracy, government regulations and a lack of influence with other relevant branches of government. A spokesman for Chunghwa Telecom in Taiwan presented this perspective in an interview with Communication International. "It is difficult for Chunghwa to improve its mobile networks as equipment procurement is still under MOTC control. [Private] operators can buy what they want and expand at any time, but we cannot, as we have to go 
through a tender procedure" said a spokesman for Chunghwa (David Hayes, Communication International, 10/01/97 p. 75). Furthermore, Chunghwa officials claim that they are forced by the government to make 80 percent of their investments in extending local loops which brings in only 30 percent of revenue due to implicit and explicit subsidies. Chunghwa also claims that the government pressures them to offer interconnection to new cellular operators at a discount to avoid any cases of market failure (David Hayes, Communication International, 10/01/97 p. 75). Officials at state-owned companies in other countries lamented that "my first impression when I started working for [dominant firm] was that I needed to respond to the market but I couldn't because it's always perceived as predatory. I have had many frustrating experiences. As a result, we are perceived as being slow. It's not true." Also, "of course the private sector wants to keep their money but what are we to do if we have no payments and few subscribers? It takes time to develop competition... We have been a state-owned enterprise for a long time. We have never conducted our business like a business." Another public sector official proposed an interesting solution: "a level playing field requires the government to make sure that everyone has the same costs."

\section{Feedback Effects}

A third consideration that is particularly important for managers devising strategies to address political risk is the strategy's dynamic integrity, specifically, the possibility of a "feedback effect." The broader literature on political risk management advises the adoption of $e x$ ante safeguards, e.g., taking on a local partner with privileged access to the government, or shortening the period during which capital returns are at risk by structuring a deal to "front-load" the cash flows (Moran, 2000; Wells et al., 1995). However, a local partner becomes a liability if it uses its privileged access at the expense of the foreign investor. Similarly, the front-loading of returns may invite excessive scrutiny of a project. The use of foreign partners may create a 
perception that a project is not "local" enough. Government commitments are not necessarily credible. Foreign lobbying is often perceived as meddling. International arbitration can be lengthy and works only when accepted by all sides. Political risk insurance or other financial hedging instruments are available for limited terms and rarely reach beyond the replacement value of assets to encompass expected cash flows. Investors must therefore assess each potential safeguard not only with respect to the original hazard that it is intended to mitigate, but also the new risks and costs that it introduces.

One prominent example of such a tradeoff is the use of local partners by investors in Malaysia and Indonesia. Because the formal institutional supports for private infrastructure investment in these countries were so weak, investors were forced (often literally) to rely on relationships and family ties as contractual supports: "Malaysia is a difficult place to understand. The electricity sector is closely interwoven with the political process. You can only try to get the tightest kind of contractual arrangements, then you have to work on relationships.” Another interviewee reiterated: "You have to use the culture... a certain amount of patronage is necessary in any government project... there's a price for everything." Yet another, "Here, outlawyering is a waste of money. Ultimately is doesn't protect you anyway. The key component is finding the right local partner."

In Indonesia, the political and regulatory officials "found" partners for the investors. One interviewee told us that, "An Indonesian partner was suggested to us. There was no way to avoid that." The experience appears to have been repeated in virtually every IPP contract there.

Cikarang Listrando, the first major private power project in Indonesia and, later, the first to sell power back onto the national grid, was owned by President Suharto's cousin. President Suharto's son had a 10 percent stake in next major project to be signed through his business concern the 
Humpuss Group. The infamous Paiton project passed from President Suharto's second son to the brother of President Suharto's son-in-law. Bambang, the second son, later resurfaced as a director for the company that took over East Asia Power in 1997. The three-phase Tanjung Jati plant included among its many investors Suharto's second daughter (phase A); eldest daughter (phase C); and a close associate of the Minister of Planning who was brought into the venture by an adviser to the Minister of Mines Energy (phase B). Suharto's eldest daughter also controlled a 20 percent state in another project although this stake was subsequently reduced to five percent. Cal Energy shared ownership of its Dieng project with the Association of Retired Officers Businesspeople (Himpurna); and of its Patuha project with the son of the Minister of Mines and Energy. Additionally, Suharto's oldest son was reputed to be a partner of CalEnergy, although the firm vigorously denied this link (44). Finally, presidential confidante Mohammed Bob Hasan owned 10 percent of another prominent IPP. In all, 26 IPP projects were approved or, in the words on one interviewee, "shoved down the throats of PLN [the incumbent SOE] as all the kids and cronies elbowed in and demanded their own PPAs."

Following the 1997 crisis, these partnering practices proved to be of some help to private investors in Malaysia. One interviewee mapped out the surviving IPPs in the following fashion: "One furthers the interests of the BumiPatra and was supported by the ex-deputy Prime Minister who is now in jail, one furthers the interests of Mahatir, another supports Mahatir's good friend who had difficulty in his other businesses, the remaining two are large diversified Bumipatra multinationals that are shrewd political operators...” Despite widespread doubts regarding its economic viability, the largest IPP in Malaysia (the Bakun hydroelectric project) continues to resurrect itself, due in no small part to the friendship between its chairman Ting Pek Khiing and the Prime Minister (Financial Times Business Limited, 1997). In Indonesia, however, the 
partnering practices ultimately backfired and magnified investors' exposure to the crisis. In May 1998, President Suharto’s longtime confidante, B.J. Habibe, replaced him and initiated a systematic campaign against the corruption, cronysim and nepotism ("KKN" in local parlance) that characterized the Suharto regime. The Indonesian state audit agency subsequently reported that it had "found indications of corruption, collusion and nepotism on all 27 [private power] contracts" and thus believes that it has legal standing to terminate these agreements. Thus, the rational calculation to play by the rules of Suharto's Indonesia and partner with the President's family and friends created tremendous liabilities for private investors in the anti-KKN campaign that followed the end of his regime.

Another strategy that may backfire is an otherwise rational pruning of maintenance or other overhead costs. For example, support for the privatization program in Brazil waned substantially after a blackout in Sao Paulo during the Christmas holiday in 1997. Record heat and a poor pre-privatization maintenance history were certainly contributing factors, but the press and the public focused largely on the 40 percent reduction in personnel (some of whom had to be rehired to teach existing workers how to repair jury-rigged transformers), as well as the utility's record profits and weak regulatory supervision (Moffett, 1998). Another example comes from Hungary, where the state-owned utility MVM launched a campaign criticizing the supply security and performance of new market entrants. In Buenos Aires, customers who had been without power for almost a week of high temperatures following a fire at a power station operated by the Chilean firm Edesur marched in the streets nightly banging pots and pans and setting tires and an automobile on fire (Zadunaisky, 1999). An engineer interviewed by the news media claimed that the delay in reinstating power was caused by Edesur's laying off of thousands of skilled Arge ntine workers like himself (Valente, 1999). 
Ironically, even in the absence of such flashpoints, profitable entry strategy may themselves create a backlash against the status quo policy regime. Consider in this instance the experience of Chilean generators. Galal et. al. [, 1994 \#1966] document a striking decrease in the average variable costs of one privatized generating company (CHILGENER, later GENER) due largely to increased efficiency in the amount of electricity generated per unit of coal input. Further, total costs declines even more sharply due to an increase in the capacity utilization of CHILGENER's plants from approximately 50 per cent in 1985 to 83.4 per cent in 1989. Data from [Estache, 1998 \#3897:5] and [Rudnick, 1998 \#3900:3] indicate that energy line losses fell from 20.9 per cent in 1986 to 8.6 per cent in 1996 or almost 60 per cent. Fischer and Serra [, 2000 \#3899:184] report that labor productivity increased from 376 clients per worker in 1987 to 703 in 1997. Rudnick [, 1998 \#3900] reports that the ratio of GWh to employees at ENDESA increased from 2.23 in 1989 to 7.62 in 1996.

Despite the dramatic efficiency gains described above, the Chilean system was not without its detractors nor its problems. From the onset, critics argued that wealth had essentially been transferred from the state and/or consumers to the shareholders and managers of the newly privatized enterprises. As evidence for this claim they point to the one thousand fold appreciation of electric companies' shares between 1984 and 1994 [Jadresic, \#3898:60]; rates or return of 30 per cent in 1995 and return on assets as high as 20 per cent [Britan, 1998 \#3901:951] and the vast gap between the 11.4 per cent reduction in tariffs compared to the 37.4 per cent fall in the price of generation [Fischer, $2000 \# 3899$ ] combined with the reduction in line losses reported above.

The perception of profiteering dominated the experience of the efficiency gains during a conflict originating in the hundred-year drought of 1998. During that crisis, the Chilean government overturned an existing law that explicitly obviated the generator's responsibility for 
climatic conditions outside of the wholesale pricing model that included data on hydrological conditions only over the past century. Direct political intervention by Congress undermined the ability of generators to adapt to the shortage and mandated that they pay compensation for any shortfall including those caused by force majeure events such as hundred-year droughts [Basanes, 1999 \#3903]. The magnitude of these fines is substantial as the government, also responding to popular pressure, raised the upper cap from approximately $\$ 25,000$ to $\$ 6.4 \mathrm{~m}$ with 25 per cent payable up front prior to any appeal [Global Power Report, \#3906].

In the words of one interviewee, "popular pressure led to massive liabilities. Now, we have the same clients, the same price but more risk." Another interviewee explained that "the government didn't want to assume the political costs in explaining the need for sacrifice. Instead, they said we are responsible. They changed the law retroactively and instituted a monetary penalty for a condition that the law explicitly stated we were not obligated to fulfill."

\section{Conclusion}

Farsighted investors never assume that a contract is a guarantee. Rather, in the words of one interviewee, political risk "has to be actively managed. You can minimize it but never fully eliminate it even under the best regulatory design. You have to dance with the shadows. You have to go beyond what you see on the surface. A lot of it is relationships, not picking the right people but rather articulating your views and cultivating ties with people who share your goals."

In the words of Dr. Ferenc Tompa, Head of Regulatory Affairs for Hungarian operator Westel, 
"As regulatory authorities the world over have a growing appetite for regulating everything that moves in the mobile industry, operators need to move ever faster not only in innovation, but also in the regulatory domain to stay ahead of the regulatory learning curve.",

Insurers must recognize that learning, articulating, cultivating and dancing are not achievable through financial engineering alone. Political risk identification and management capabilities differ across industries and firms within a given country. A firm's characteristics, direct and indirect ties and experiences shape its ability to influence government. Its position in the industry shapes the types of appeals most likely to generate favorable outcomes. Each financial or strategic move made to counter the government generates a countermove by the government or third parties that must be taken into account. Successful management of political risk on an ongoing basis requires the cooperation of country experts, risk analysts and senior

${ }^{7}$ Evidence of the potential for learning about political hazards in the infrastructure sector comes from Holburn (2002) who finds patterns of entry in the independent power production industry over time that suggest firms that have previously operated under rate-of-return regulation are better equipped to manage the rate review process, while firms with experience in wholesale market competition are better able to manipulate prices under complex market rules. Similarly, firms with experience in countries with a specific institutional profile (e.g., centralized political decision-making or a strong independent regulator) enjoy a comparative advantage in other countries with similar institutional structures. Even in studies that span non-regulated industries, patterns of entry (Delios \& Henisz, 2003, Henisz \& Delios, 2001), entry mode (Delios \& Henisz, 2000) and survival (Henisz and Delios, 2002) suggest that investing firms look to their past experiences in similar markets to help them shape their entry strategies in new markets that share certain political or market characteristics. Where they possess relevant internal information, they are less likely to avoid a country based on its level of political hazards or rely upon a local partner through an equity joint venture. Their survival probabilities are also enhanced relative to their less experienced peers. 
management. Such insight into the firm-specific nature of political risk management is an essential dimension of competition in the turbulent and uncertain policy environment that increasingly surrounds the multinational enterprise. An insurer's ability to appreciate these strategic aspects of political risk management will directly influence the accuracy of their pricing and cover limits and, ultimately, their profitability and survival.

\section{REFERENCES}

Corn, David. 2002. Enron and the Bushes, The Nation.

Delios, Andrew \& Witold J. Henisz. 2000. Japanese Firms' Investment Strategies in Emerging Economies. Academy of Management Journal, 43(3): 305-23.

Delios, Andrew \& Witold J. Henisz. 2003. Political Hazards, Experience and Sequential Investment Strategies: The International Expansion of Japanese Firms, 1980-1998. Journal of International Business Forthcoming.

Financial Times Bus iness Limited. 1997. Matathir's Bakun Lifeline Scares Forex Market, FT Energy Newsletters - Power in Asia.

Financial Times Business Reports Business File. 1995. Politics Influence GSM Tender.

Government, New Zealand. 1995. State Owned Enteprise Act. Wellington.

Henisz, Witold J. \& Andrew Delios. 2001. Uncertainty, Imitation, And Plant Location: Japanese Multinational Corporations, 1990-1996. Administrative Science Quarterly, 46(3): 443-75.

Holburn, Guy. 2002. Political Risk, Political Capabilities and International Investment Strategy: Evidence from the power generation industry. Mimeo.

Johnstone, Chris. 2001. United Energy Threatening New Energy Regulator with Legal Action, Prague Business Journal.

Kobrin, Stephen, John Basek, Stephen Blank, \& Joseph La Palombara. 1980. The Assessment and Evaluation of Noneconomic Environments by American Firms: A preliminary report. Journal of International Business Studies, 11(1): 32-47.

Merchant International Group. 1999. The Intelligence Gap. London.

Pfeffermann, Guy \& Gregory Kisunko. 1999. Perceived Obstacles to Doing Business: Worldwide Survey Results. Mimeo.

Root, Franklin R. 1968. Attitudes of American Executives Towards Foreign Governments and Investment Opportunities. Economics and Business Bulletin, 20(January): 14-23.

Spar, Deborah. 1995. White Nights and Polar Lights: Investing in the Russian Oil Industry. HBS Case, 9-795-022.

Wei, Shang-Jin \& Thomas W. Hall. 2001. Investigating the Costs of Opacity: Deterred Foreign Direct Investment: PriceWaterhouseCoopers Report. 